\title{
LITHOLOGO-MINERALOGICAL RESEARCHES OF OLIGOCENE DEPOSITS OF NORTH-WESTERN SHELF OF BLACK SEA FOR THEIR CORRELATION G.V. Klyushuna
}

\section{ЛІТОЛОГО-МІНЕРАЛОГІЧНЕ ДОСЛІДЖЕННЯ ОЛІГОЦЕНОВИХ ВІДКЛАДІВ ПІВНІЧНО-ЗАХІДНОГО ШЕЛЬФУ ЧОРНОГО МОРЯ 3 МЕТОЮ КОРЕЛЯЦІї Г.В. Клюшина}

The results of the detailed lithological and mineralogical research of Oligocene sediments of north-western shelf of the Black sea on a complex methodical basis are executed. The peculiarities of lithological features distribution through stratigrafical levels are exposed.

Key words: the Black Sea, north-western shelf, Oligocene, material composition, correlation.

Виконано детальне літолого-мінералогічне дослідження олігоценових відкладів північно-західного шельфу Чорного моря на комплексному методичному підґрунті. Виявлено приуроченість чітких літологічних ознак до певних стратиграфічних рубежів.

Ключові слова: Чорне море, північно-західний шельф, олігоцен, речовинний склад, кореляція.

\section{ВСТУП}

Незважаючи на багаторічну історію вивчення майкопських відкладів Південного нафтогазоносного регіону України, невирішеними залишаються ще багато важливих питань будови і кореляції цього своєрідного породного комплексу. Значною мірою це зумовлено складною тектонічною структурою регіону, що спричинила різки зміни в розподілі потужностей і створила своєрідні умови седиментації, які відрізняють відклади майкопської серії від всіх відомих комплексів осадових утворень.

Олігоценові відклади північно-західного шельфу Чорного моря, що є об'єктом наших досліджень, за стратиграфічними схемами фанерозою та докембрію України [5] представлені планорбеловим, молочанським, сірогозьким, асканійським та горностаєвським горизонтами. Але, як показали подальші дослідження [1, 3], для цієї області чітко відокремлюються три трансгресивно-регресивні комплекси. Тому було запропоновано в ранзі регіоярусів вживати такі: планорбеловий і молочанський (нижній олігоцен, рюпельський ярус загальної стратиграфічної шкали), та керлеутський (верхній

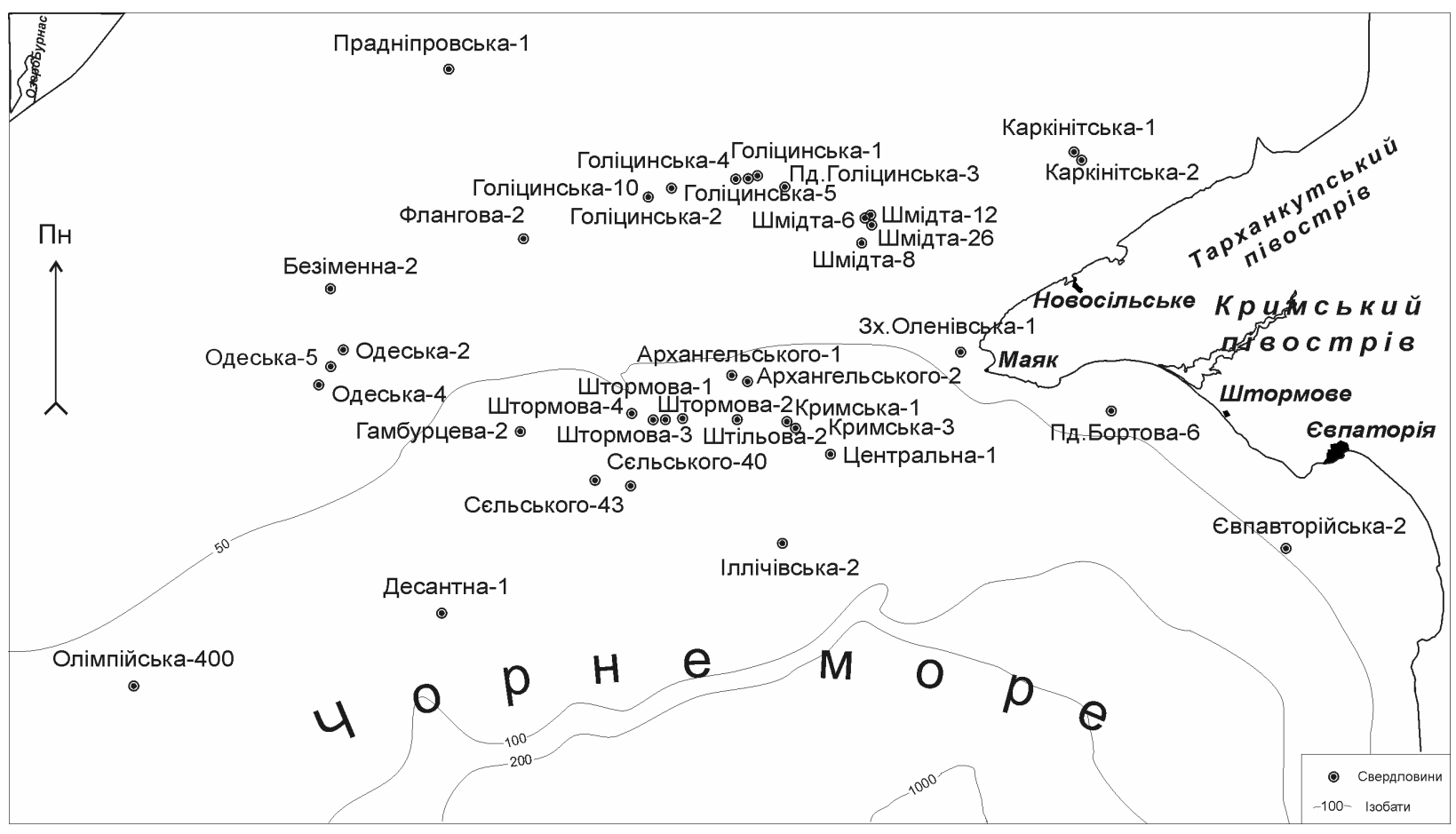

Рис. 1. Схема фактичного матеріалу 
олігоцен, хатський ярус). Термін «майкопська серія» (товща, майкоп) вживається для відкладів олігоцену - нижнього міоцену в Кримсько-Кавказькій нафтогазоносній провінції, де існують інші схеми підрозділу на світи, горизонти, регіояруси [4].

\section{МАТЕРІАЛИ I МЕТОДИ}

Серед важливих літологічних ознак, що широко застосовуються при кореляції теригенних та інших відкладів, варто відмітити такі: тип (пісковики, алевроліти, глини, вапняки тощо), колір, структура, текстура, склад породоутворюючих, аутигенних, акцесорних мінералів, їх сортування, окатаність та ступінь перетворення. Всі разом і кожен окремо вони виступають як літологічні критерії, які значно доповнюють біостратиграфічні корелятиви, а при їх відсутності або малоінформативності є основними для розчленовування і кореляції осадових товщ.

Окрім детального літологічного дослідження кернового матеріалу і петрографічних шліфів речовинний склад олігоценових порід вивчався за результатами гранулометричного, хімічного і спектрального аналізів, мінеральний склад глинистої фракції визначався рентгеноструктурним методом, склад органічної речовини - люмінесцентно-бітумінологічним (рис. 1).

На підставі комплексних даних, отриманих різними методами досліджень, а також завдяки точній віковій прив'язці вдалося побудувати графіки розподілу гранулометричних фракцій та основних хімічних компонентів у розрізі олігоцену, а також встановити приуроченість чітких літологічних ознак до певних стратиграфічних рубежів. Стратиграфічна колонка з літологічними різновидами порід окреслювалася ліворуч, а всі литолого-мінералогічні особливості олігоценових порід наносилися праворуч (рис. 2).

\section{РЕЗУЛЬТАТИ ДОСЛІДЖЕНЬ ТА ЇХ АНАЛІЗ}

На території північно-західного шельфу Чорного моря відклади олігоцену розкриті на більшості підняттів на глибині від 300 до 1500 м. Вони представлені здебільшого теригенними породами (пісковики, алевроліти, глини), значно менш поширені біо- та біохемогенні (мергелі, вапняки тощо). Всі літологічні типи порід не зазнали значних катагенетичних змін і зберегли основні риси, що характерні для початкових стадій осадкоутворення, а саме седименто- та діагенезу. Спостерігається головним чином ущільнення порід при незмінності глинистого цементу і присутність новоутворень, зокрема опал-кристобаліту, халцедону або кварцину, в порожнинах і тріщинах.

Відклади планорбелового регіоярусу (планорбелова світа) розкриті свердловинами майже на всіх підняттях північно-західного шельфу. Загальна потужність - до 640 м. Залягають узгоджено чи 3 переривом на мергельно-глинистих відкладах альминської світи.

Нижня частина розрізу світи складена глинами сірими із зеленуватим відтінком, іноді темно-сірими з слабким брунатним відтінком, щільними, слюдистими з рідкісними прошарками та присипками світло-сірих алевритів. Текстура порід лінзоподібна, плямиста, зумовлена нерівномірним розподілом уламкових зерен. Основна глиниста маса каолініт-гідрослюдиста, містить домішок мікрозернистого кальциту та кварцу. Уламковий матеріал (розмір 0,03-0,08 мм) в породах добре відсортований, представлений кутастими зернами кварцу, польовими шпатами, уламочками кременистих порід, лусочками мусковіту. Аутигенні мінерали представлені сидеритом, глауконітом і піритом. Пірит присутній постійно у мінливій кількості, утворює численні вкраплення, утворення неправильної, кулястої та видовженої форми. Сидерит зустрічається рідко, утворює дисперсні комковаті скупчення брунатного кольору. Глауконіт (вміст сягає 1\%) трапляється у вигляді мікроагрегатних утворень неправильної форми зеленого або бурувато-зеленого кольору, розмір яких відповідає розміру уламкових зерен. Акцесорні мінерали зустрічаються рідко, найчастіше представлені цирконом, турмаліном, гранатом, сфеном.

В районі Одеського підняття нижня частина планорбелової світи складена глинами зеленуватосірими з рідкісними прошарками погано відсортованих пісковиків. Потужність - до 130 м.

Для верхньої частини розрізу планорбелової світи характерно зменшення вмісту біогенної кальцитової складової і поступове збільшення кількості уламкових зерен алевритової розмірності (5-10\%). Вона представлена зеленувато-темно-сірими щільними, слабослюдистими глинами з плитчастою окремістю і поодинокими присипками сірого і світло-сірого алевритового матеріалу по площинам нашарування. Розкрита свердловинами в північно-східній частині шельфу, де має значні потужності - до 500 м. 

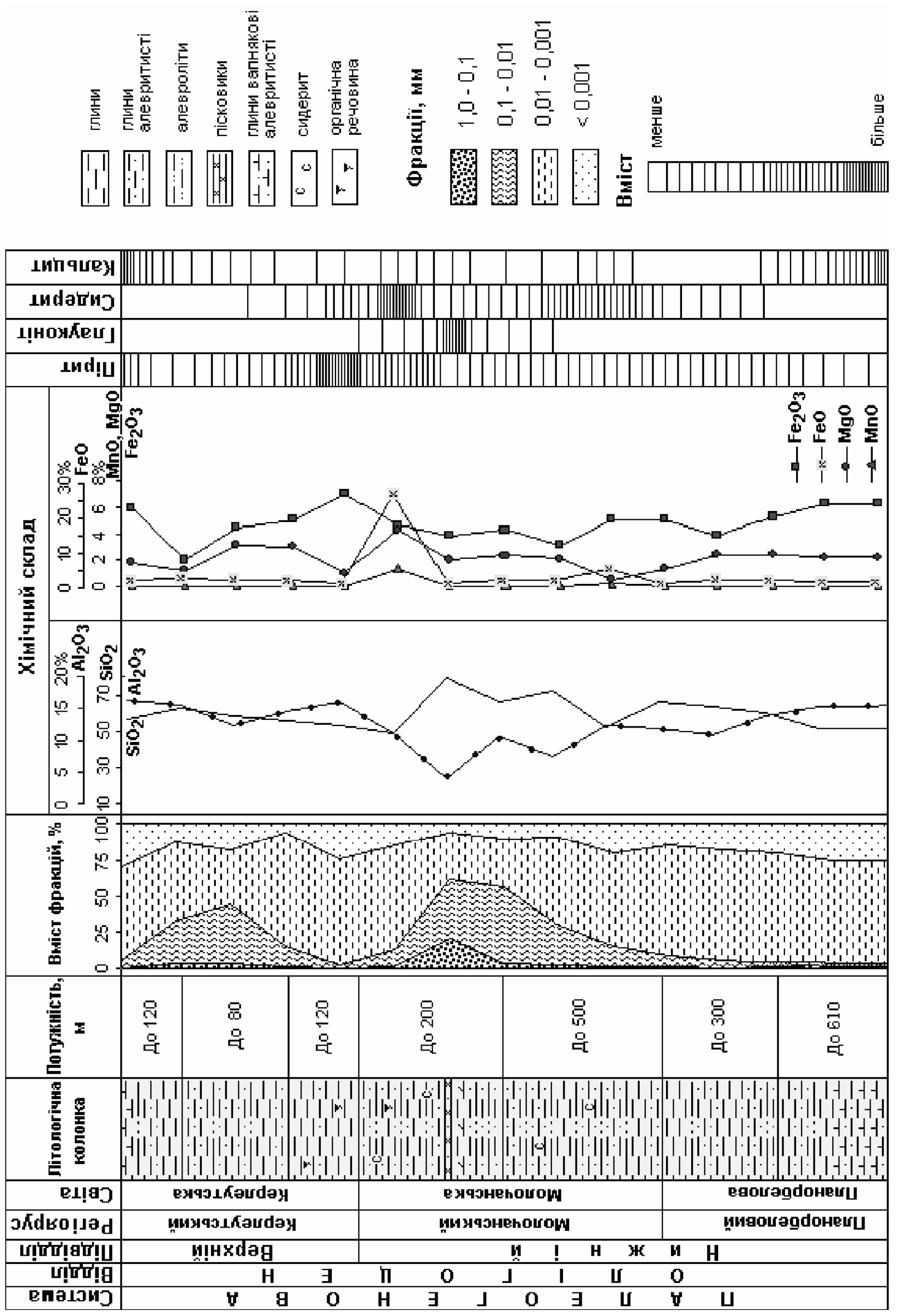

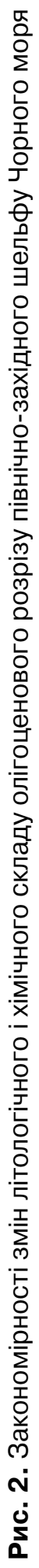


Відклади молочанського регіоярусу (молочанська світа) виявлені на всіх підняттях північнозахідного шельфу і $€$ найбільш вивченими. Вони залягають узгоджено чи з переривом на відкладах планорбелової світи та перекриваються глинисто-алевритовим комплексом керлеутської світи. Максимальна потужність - до 500 м.

Молочанські відклади двокомпонентні. Нижня частина розрізу представлена перешаруванням світло-сірих, слабозцементованих глинистих алевролітів із зеленувато-темно-сірими масивними глинами. Верхня $€$ основною продуктивною товщею, якій властива літологічна різноманітність. Вона складена зеленувато-сірими, сірими або темно-сірими алевролітами і глинами, меншою мірою пісковиками, сірувато-зеленими глауконітовими пісковиками та сіро-брунатними сидеритовими породами, що ритмічно перешаровуються. Для порід характерні різноманітність структурних і текстурних особливостей, погане сортування уламкового матеріалу, поліміктовий склад глинистих мінералів, збільшення вмісту акцесорної та аутигенної складових, значна кількість вуглефікованого рослинного детриту.

Мікротекстура порід хаотична, ділянками неясноорієнтована, плямиста. Часте тонке перешарування глинистого та уламкового матеріалів обумовлює лінзоподібну і мікрошарувату текстури. Нерідко мікрошаруватість підкреслюється орієнтованим розташуванням волокон вуглефікованого рослинного детриту та видовжених уламкових зерен. Цемент належить до базального та контактнопорового типів. Глинисті мінерали представлені монтморилонітом, гідрослюдою, каолінітом, рідко хлоритом.

Кластичний матеріал складений зернами кварцу - до 80\%, польових шпатів - 20-25\% (ортоклаз, рідко мікроклін і альбіт), лусочками мусковіту та поодинокими уламками кременистих порід. Зерна розміром понад 0,1 мм різною мірою обкатані, а 0,1 мм і менше - переважно кутасті, часто кородовані глауконітом. У групі акцесорних мінералів переважають турмалін, гранат, циркон, монацит.

Вміст сидериту, глауконіту і біогенного кальциту у молочанських відкладах набуває породоутворюючого значення. Породи збагачені сидеритом (вміст 20-40, рідко - 75-95\%), зустрічаються у вигляді лінз та прошарків потужністю до 0,3 м, а також різноманітних за розміром конкреційних стягнень (2 см і більше). Як правило, вони дуже міцні, важкі, і мають брунатне забарвлення. Глауконітові пісковики утворюють прошарки зеленувато-сірого кольору, потужністю від 0,3 до 1,5 м. Вміст аутигенного глауконіту в них сягає $10-15 \%$.

Вапняки органогенно-детритусові встановлені на підняттях Південно-Голіцинському та Олімпійському у вигляді прошарків (до 1 м). Вони складені різнозернистим органогенним детритом (30-70\%) та глинисто-карбонатною речовиною. Детрит представлений уламками кальцитових форамініфер і кріноідей, а також спікулами губок, заміщених вторинним зернистим кальцитом [2].

Керлеутський регіоярус (керлеутська світа) узгоджено або з переривом залягає на відкладах молочанського регіоярусу, перекривається батисифоновою світою кавказького регіояусу міоцену. Це потужна трикомпонентна карбонатно-алеврито-глинисто товща, яка за літологічним складом чітко відрізняється від нижчезалягаючих відкладів. У нижній частині вона представлена глинами темносірими, майже чорними, інколи зеленувато-сірими, різною мірою алевритистими, слюдистими, ущільненими, тонко- або неясношаруватими, часом в'язкими, з дзеркалами ковзання. Структура породи сплутано-волокниста або фітоалевропелітова. Глинисті мінерали представлені монтморилонітом, хлоритом і гідрослюдою. Уламковий матеріал (5-15, рідко - до 50\%) розподілений нерівномірно у вигляді присипок, згустків, лінзоподібних включень, тонесеньких прошарків. Для порід характерні значний вміст органічної речовини $\left(\mathrm{C}_{\text {орг }}-0,93-1,59 \%\right)$, а також найбільші показники вмісту аутигенного піриту (до 10\%), часто окисленого до чорного, лімонітизованого. Максимальна потужність - до 120 м.

Для другої пачки характерно тонке перешарування зеленувато-сірих алевритистих безкарбонатних щільних глин і світло-сірих із зеленуватим відтінком алевритів та помітне збільшення вмісту уламкового псамітового матеріалу (до 10\%). Глинисті мінерали представлені монтморилонітом, гідрослюдою і каолінітом, аутигенні - тонкорозсіяним піритом і лімонітом, інколи глауконітом, сидеритом, цеолітом, колофаном. Потужності коливаються в межах 35-120 м.

Верхня частина розрізу керлеутської світи складена темно-сірими, зеленувато-сірими, іноді зі слабким брунатним відтінком карбонатними глинами, щільними, тонкошаруватими, що містять до 10\% кластичного алевритового матеріалу, представленого кутастими зернами кварцу, рідше польо- 
вих шпатів, лусочками мусковіту. Глинисті мінерали представлені гідрослюдою і монтморилонітом. Серед аутигенних мінералів визначено пірит і кальцит, поодинокі утворення глауконіту і сидериту. Органогенний детрит представлений кальцитовими черепашками форамініфер, уламками фосфатної органіки, опаловими спікулами губок та діатомеями (до 0,16 мм). Потужність - до 360 м.

Аналіз потужностей свідчить, що найбільші потужності відклади олігоцену (понад 1500 м) мають в Каркінітському прогині (Михайлівська западина). Ця ділянка характеризується і найбільш повним розрізом, причому олігоценові відклади згідно перекривають мергельно-глинистий комплекс верхнього еоцену. У західному напрямку, в районі підняттів Безіменне, Гамбурцева, Одеське спостерігається різке скорочення потужностей олігоценових відкладів, а в межах валу Губкіна і Кілійсько-Зміїного підняття вони не встановлені.

\section{ОБГОВОРЕННЯ РЕЗУЛЬТАТІВ ТА ВИСНОВКИ}

Вивчення гранулометричного складу порід олігоцену показало, що найбільш важливим фактором, який впливав на склад відкладів, було надходження теригенного, насамперед пелітового й алевритового матеріалу. Максимум вмісту уламкової псамітової компоненти властивий верхній частині розрізу молочанської світи. Біогенний матеріал (рештки кальцитових черепашок, спікули губок та ін.) міститься у породах у підпорядкованій кількості. Винятком є лише район Крайового уступу, де розріз олігоцену представлений перешаруванням теригенно-біогенних і біогенних порід.

Склад глинистих мінералів одноманітний і практично не змінювався впродовж всього періоду осадконакопичення. Переважаючими мінералами є монтморилоніт, гідрослюда і каолініт, домішок складає хлорит. Всі вони є теригенними, без помітних ознак діагенетичного перетворення.

Спостерігається чітка закономірність у розподілі в розрізі олігоцену аутигенних мінералів, зокрема зональність складу карбонатів, яка виявляється в присутності сидеритових прошарків у середній частині розрізу олігоцену, а біогенного кальциту - у нижній і верхній, а також наявність алеврито-піщанистих глауконітових прошарків у верхній частині молочанської світи (рис. 2).

Таким чином, проведені дослідження свідчать про великі можливості мінералого-петрографічного і структурно-генетичного аналізів для розчленовування і кореляції продуктивних товщ майкопської серії Південного нафтогазоносного регіону України та уточнення стратиграфічних границь в її межах.

1. Гожик П.Ф., Митропольський О.Ю., Маслун Н.В., Цихоцька Н.Н. Особливості седиментогенезу в Чорноморській западині в кайнозої // Геология и полезные ископаемые Черного моря. - Киев, 1999. - С. 278-284.

2. Клюшина А.В. Сравнительная литологическая характеристика олигоценовых отложений поднятий Голицына и Олимпийское // Сучасні проблеми геологічної науки. - К., 2003. - С. 101-104.

3. Маслун Н.В., Клюшина Г.В. Особливості стратиграфічної будови майкопських відкладів північнозахідного шельфу Чорного моря // Матеріали 6-ї
Міжнарод. конф. «Геодинаміка, сейсмічність і нафтогазоносність Чорноморсько-Каспійського регіону» (Україна, Крим, 12-16 верес. 2005 р.). - Сімферополь, 2005. - C. 45-47.

4. Маслун Н.В., Цихоцька Н.Н., Клюшина Г.В. Стратиграфія олігоценових відкладів північно-західного шельфу Чорного моря // Геол. журн. - 2004. - № 4. C. 16-27.

5. Стратиграфическая схема фанерозойских образований Украины для геологических карт нового поколения: Графические приложения. - Киев, 1993. 